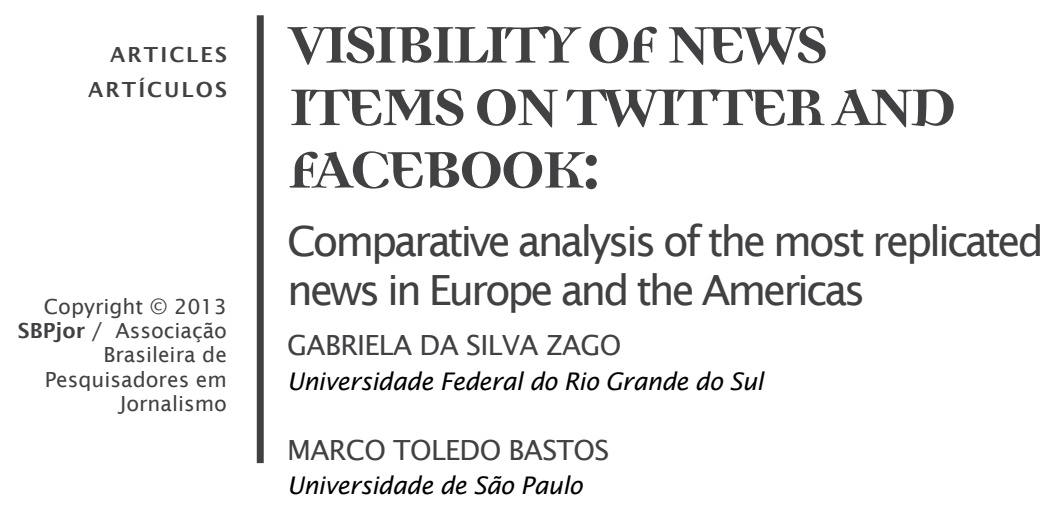

\begin{abstract}
This paper identifies and compares the top replicated news items on Twitter and Facebook, on news websites from Brazil, Germany, Spain, the United States and United Kingdom. The data includes 8 of the newspapers with the largest circulation in the 5 countries, totaling 40 outlets. The volume of "retweets" and "likes" was used as a metric for representing the visibility of news items. Links posted on Twitter and messages posted by newspapers on Facebook were collected for a period of two weeks during October 2012. Content analysis was carried out for the top 25 replicated messages in each social network, which uncovered significant cultural traits and editorial differences across countries, based upon the content that circulated on social networks during the period. The results confirm users' perceptions of social networking sites, with Facebook being used largely for entertainment and recreation, and Twitter for covering political, economic, and social events.
\end{abstract}

Keywords: News. Journalism. Circulation. Twitter. Facebook

\title{
VISIBILITY OF NEWS ITEMS ON TWITTER AND FACEBOOK: Comparative analysis of the most replicated news in Europe and the Americas
}

\begin{abstract}
RESUMO - O artigo identifica e compara as notícias mais repercutidas no Twitter e no Facebook em jornais do Brasil, Alemanha, Espanha, Estados Unidos e Reino Unido. O recorte inclui 8 dos jornais de maior circulação nos 5 países, perfazendo um conjunto de 40 periódicos. O volume de "retuites" e "curtidas" foi utilizado para avaliar a visibilidade da notícia. Links postados no Twitter e mensagens postadas pelos jornais no Facebook foram coletados durante duas semanas em outubro de 2012. Para tanto, foi analisado o conteúdo das 25 mensagens mais replicadas em cada jornal e rede social, de forma que encontramos características culturais e diferenças editoriais significativas entre países em função dos conteúdos que circularam nas redes sociais durante o período. Os resultados também oferecem uma confirmação empírica da percepção generalizada de que o Facebook é utilizado majoritariamente para conteúdos ligados ao entretenimento e curiosidades, e o Twitter para a cobertura de eventos políticos, econômicos e sociais. Palavras-chave: Notícia. Jornalismo. Circulação. Twitter. Facebook
\end{abstract}




\section{VISIBILIDAD DE NOTICIAS EN TWITTER Y EN FACEBOOK: Análisis comparativo de las noticias con mayor repercusión en Europa y las Américas}

RESUMEN - El artículo identifica y compara las noticias con mayor repercusión en Twitter y Facebook en periódicos de Brasil, Alemania, España, Estados Unidos y Reino Unido. La muestra seleccionada se compone de cuarenta periódicos e incluye ocho de los diarios de mayor circulación en los cinco países. El volumen de retuiteos y "me gusta" se utilizó para evaluar la visibilidad de la noticia. Para ello, se recolectaron enlaces publicados en Twitter y mensajes publicados por los periódicos en Facebook durante dos semanas en octubre de 2012. A continuación, se analizó el contenido de los veinticinco mensajes más replicados en cada diario y red social, de forma que se encontraron características culturales y diferencias editoriales significativas entre países en función de los contenidos que circularon en las redes sociales durante ese período. Los resultados también ofrecen una confirmación empírica de la percepción generalizada de que Facebook es utilizado mayoritariamente para contenidos relacionados con el entretenimiento y las curiosidades, y Twitter para la cobertura de acontecimientos políticos, económicos y sociales. Palabras clave: Noticia. Periodismo. Circulación. Twitter. Facebook.

\section{INTRODUCTION}

The interest in the mechanics of news circulation is continually revisited due to structural change in the channels and forms of distribution. An overview of different communication structures throughout history includes oral stories passed from generation to generation. In Ancient Rome, news about government figures circulated through gossip. In Greece, stories were dramatized. Since their emergence in the $17^{\text {th }}$ century, printed newspapers have been delivered directly to home subscribers, distributed in hotels and restaurants, and sold on street corners. As new media channels emerge, the circulation of news has undergone structural changes, with the circulation of newspaper increasingly reliant on intermediaries to ensure that news reaches larger geographical areas.

The Internet has had a sizeable impact on the circulation of news and the metrics for weighting and measuring different platforms. Although newspapers can be "distributed" through mechanisms such as RSS and paid subscriptions, access to news items can depend on multiple, daily visits to the newspaper website or specific news items. While the circulation of news was previously measured by the quantity of newspaper editions distributed, it is now dependent on a number of metrics or indicators for the relationship between circulation and feedback to news items, including the volume of access to news items 
and time spent on newspaper websites. In this context, news outlets have been developing strategies to attract potential readers to their websites. One of these strategies is to post links to news articles on social media sites, particularly on Twitter and Facebook.

News circulation is the part of the newsmaking process whereby content is disseminated after it is produced (MACHADO, 2008; THORN; PFEIL, 1987), a process that is increasingly dependent on the use of social media (ZAGO, 2012). Links to news articles can be posted on newspaper profiles on social network sites such as Twitter and Facebook, and by users on their personal profiles. Once published, these messages can be replicated by interconnected users that "like" and "retweet" links to the articles.

This article analyzes the types of messages that are spread most frequently and how the most replicated updates vary across different newspapers around the world. The aim is to identify and compare the content of the top replicated messages on Twitter and Facebook in 40 outlets from 5 countries: Brazil, Germany, Spain, the United States and United Kingdom. Eight newspapers were selected from each country based on the print circulation, which allowed for comparison of the relative importance of each outlet, online and offline. The analyses presented here identify regional differences and similarities, highlighting global news coverage of world events in the five countries during the period of this study.

The article is organized as follows: first, the particularities of news circulation on social networks are outlined. Second, the period covered in this study is described, as well as the nature of the data and the methodological procedures employed in the research. Third, the results are discussed. Finally, the last section devotes attention to a broader discussion about the analysis.

\section{NEWS CIRCULATION ON SOCIAL NETWORKS}

News circulation is a complex process that includes both the provision of journalistic material through traditional channels of diffusion (print, web, radio and TV), and distribution through supplementary channels used by outlets to publicize their content (MACHADO, 2008; THORN; PFEIL, 1987) - which also includes social networking sites. On social networks, however, users' feedback to content significantly impacts the distribution of news articles, as diffusion and readership of 
news is directly dependent on the activity of interconnected users.

By using social network sites to distribute news, newspapers not only provide access to their content, but also allow for users to participate in the process of determining which news items will circulate. In this article, replication and recirculation are understood in terms of content reproduction (ZAGO, 2012) that leads to information diffusion (JENKINS; FORD; GREEN, 2013). This process is enhanced both by "retweets" on Twitter and by "likes" on Facebook. The act of "liking" or "retweeting" a news piece makes it possible for content to be exhibited to the contacts of the user that "liked" or "retweeted" the article. This replication provides further visibility for the article by enlarging the potential audience. The mechanics of replication and circulation on social media also provide an objective and reliable metric to measure news readership - perhaps more reliable, and certainly more objective, than print circulation.

When articles are replicated, the content is made available to a wider range of users that can potentially start new cascades from the original material. This principle of network connection allows information to pass through a number of subnetworks in a cascade effect (RECUERO, 2009), a phenomenon popularly known as "going viral." Although this networked scenario presents unique opportunities for news circulation, the policies of news outlets toward social media vary greatly. While a portion of news outlets have professionals dedicated to social media, the strategy of a large number of newspapers is restricted to reproducing the content available on the website via news feeds (ZAGO; RECUERO, 2011). The different approaches to social media mirror the circulation of news items and determine the relative importance of each newspaper within a country.

Although many studies have discussed the relationship between journalism and social network sites such as Twitter and Facebook (BRUNO, 2011; BRUNS; HIGHFIELD, 2012; DALMASO, 2012; HERMIDA, 2012; JÚNIOR, 2013; PRIMO, 2011; VIS, 2012), research dedicated to the potential of social media for news circulation is still forthcoming (KISCHINHEVSKY, 2012; NEWMAN, 2011; ZAGO, 2012). In terms of content, the use of social networking sites in journalism is associated with hard news, soft news and general news (CONOVER et al, 2011; HARGITTAI; LITT, 2011 ). However, there is a lack of studies that compare news content from a wide range of international outlets (MITCHELSTEIN; BOCZOWSKI, 2009), especially on Twitter and Facebook

Although the use of hard and soft news to classify news items is highly controversial, hard news is usually associated with the public 
debate and conveyed in informative and objective news about politics, economics, and security. Soft news, on the other hand, is normally associated with entertainment topics, but also with culture, sports, and lifestyle. Rainemann et al (2012) offered three dimensions to set apart hard and soft news: topic (politically relevant vs politically irrelevant), focus (society vs individual; thematic vs episodic) and style (impersonal vs personal; not emotive vs emotive). Thus, even if a news piece is about an economics-related issue, it is possible for the content be considered soft news due to editorial choices that emphasize specific elements of the story.

\section{METHODOLOGICAL PROCEDURES}

The top replicated news articles from 40 newspapers (Table 1) on Twitter and Facebook during the first two weeks of October 2012 (October $1^{\text {st }}$ to $14^{\text {th }}$ ), were compared and identified. A content analysis was carried out of the 25 top replicated messages on Twitter and Facebook during the period. Whenever messages presented links, attention was focused on the section in which the corresponding news piece was placed to determine the content. When no link was present, the classification was based on the message accompanying the link on the social networking sites. Data was tabulated in order to combine news sections across different countries' ${ }^{1}$.

Data collection depended on the possibilities presented by Twitter and Facebook APIs. An API (Application Programming Interface) is an interface or matrix of resources that renders possible the programming and execution of routines, following a set of rules (API guidelines). This interface allows programmers to access resources that are not normally made available for the final user. Methods of interaction with the API depend on the communication protocol implemented at the server side. Facebook API is based on the REST protocol and therefore the transfer of information depends on individual HTTP requests and responses. Twitter also offers a REST API, but for the purposes of this investigation the authors relied on a Streaming API that instead of requiring individual requests allows for the establishment of a permanent connection with a Twitter API, through which data is transferred when entities are encountered within the source document (StAX event based). 
VISIBILITY OF NEWS ITEMS ON TWITTER AND FACEBOOK

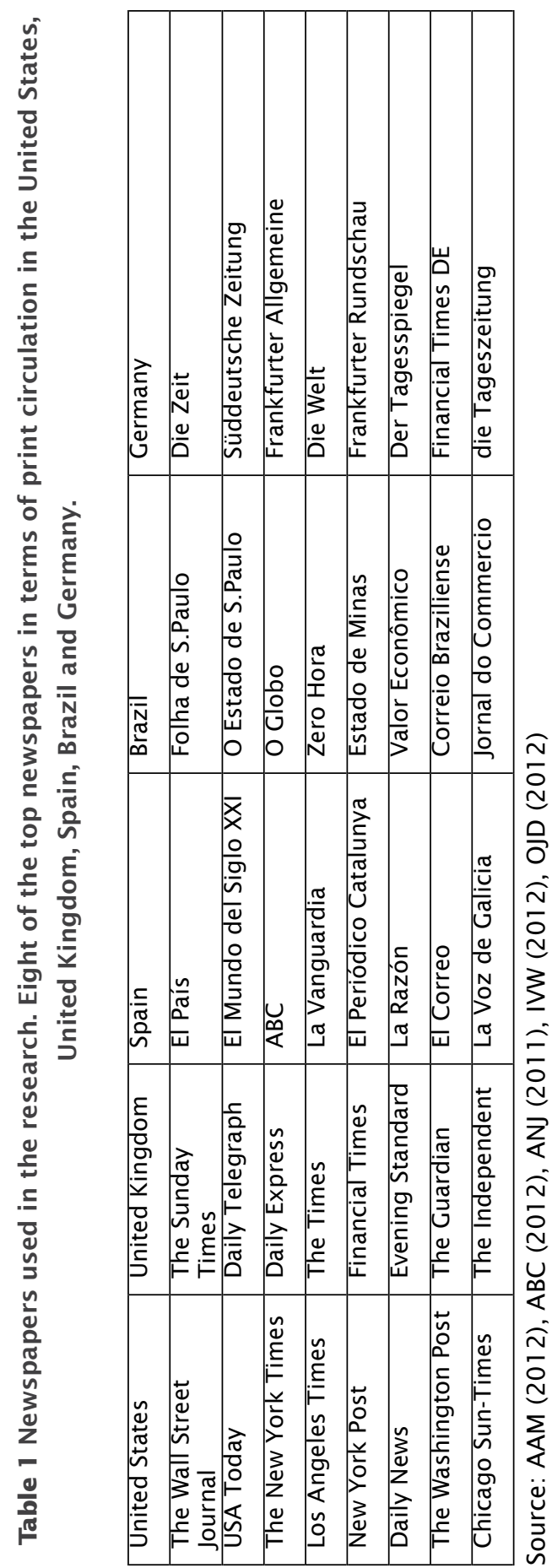

BBAZILIANJOURNALLSM RESEARCH-Volume 9-Number I- zоІ3| 119 
Due to the options offered by Twitter APIs, data collection from the Streaming API allowed for monitoring messages containing links to the newspapers, including messages posted by individual users and messages posted by official newspaper profiles. On Facebook, data collection was restricted to updates posted by the newspapers on the official pages of the social network, thus including only content made available directly by the outlet. Messages were collected at the end of the research period via a series of requests on Facebook's API. Data was later organized by newspapers in a frequency table, organized into top liked and top retweeted messages ${ }^{2}$.

\section{RESULTS AND DISCUSSION}

The top replicated news items varied significantly across newspapers and within each country. They also varied - perhaps confirming users' expectations - according to the social networking site. In countries like Germany, Brazil and Spain, "politics" appeared as the top replicated topic on Twitter (Table 2), whereas "entertainment" and "culture" appeared among the top liked topics on Facebook (Table 3) in a significant portion of the newspapers analyzed. Although the figures presented in this study do not include the totality of the items posted on Twitter and Facebook during the period, the identification of the top 25 most replicated topics sheds light on topics that gained significant visibility in the period.

Table 2 News section of the top replicated news on Twitter.

\begin{tabular}{|l|l|l|l|}
\hline Country & Topic 1 & Topic 2 & Topic 3 \\
\hline Germany & $\begin{array}{l}\text { Politics } \\
(28.63 \%)\end{array}$ & $\begin{array}{l}\text { Economy } \\
(14.09 \%)\end{array}$ & $\begin{array}{l}\text { Local (8.63\%) } \\
\text { and National } \\
\text { news (8.63\%) }\end{array}$ \\
\hline Brazil & $\begin{array}{l}\text { Politics } \\
(29.05 \%)\end{array}$ & $\begin{array}{l}\text { Local news } \\
(15.24 \%)\end{array}$ & $\begin{array}{l}\text { Entertainment } \\
(14.76 \%)\end{array}$ \\
\hline Spain & $\begin{array}{l}\text { Politics } \\
(20.4 \%)\end{array}$ & $\begin{array}{l}\text { Local news } \\
(13.43 \%)\end{array}$ & $\begin{array}{l}\text { Economy } \\
(11.94 \%)\end{array}$ \\
\hline United States & $\begin{array}{l}\text { Opinion } \\
(12.93 \%)\end{array}$ & $\begin{array}{l}\text { Entertainment } \\
(12.43 \%)\end{array}$ & Politics (9.45\%) \\
\hline United Kingdom & $\begin{array}{l}\text { Sports } \\
(17.7 \%)\end{array}$ & $\begin{array}{l}\text { Opinion } \\
(12.92 \%)\end{array}$ & $\begin{array}{l}\text { National } \\
(10.52 \%)\end{array}$ \\
\hline
\end{tabular}

Source: elaborated by the authors 
Table 3 News section of the top replicated news on Facebook.

\begin{tabular}{|l|l|l|l|}
\hline Country & Topic 1 & Topic 2 & Topic 3 \\
\hline Germany & $\begin{array}{l}\text { Entertainment } \\
(21.18 \%)\end{array}$ & $\begin{array}{l}\text { Culture } \\
(15.27 \%)\end{array}$ & $\begin{array}{l}\text { Politics } \\
(14.28 \%)\end{array}$ \\
\hline Brazil & Politics & Local news & Culture \\
& $(20.45 \%)$ & $(18.75 \%)$ & $(17.04 \%)$ \\
\hline Spain & $\begin{array}{l}\text { Local news } \\
(13.79 \%)\end{array}$ & $\begin{array}{l}\text { Culture } \\
(13.10 \%)\end{array}$ & $\begin{array}{l}\text { Politics } \\
(11.72 \%)\end{array}$ \\
\hline United States & Politics & Local news & Sports \\
& $(22.22 \%)$ & $(16.62 \%)$ & $(12.12 \%)$ \\
\hline United Kingdom & Opinion & National & Politics \\
& $(15.07 \%)$ & $(12.56 \%)$ & $(9.09 \%)$ \\
\hline
\end{tabular}

Source: elaborated by the authors

\subsection{Topic replicated topics on Twitter}

The top replicated topics on Twitter reveal a direct relationship with the socioeconomic and political context of each country at the time of data collection, with a predominance of news about the economy in Spain, and politics in Brazil, the United States and Spain. This can be explained due to national and regional elections in these countries during the period (regional elections in Brazil and Spain; national elections in United States). There was also a high incidence of opinion pieces in the top replicated messages on American and British newspapers. The hypothesis proposed here is that these countries, and the editorial profile of local newspapers, often include a greater set of opinion pieces and column writings.

Figure 1 Relative percentage of the top replicated topics on Twitter in the newspapers analyzed

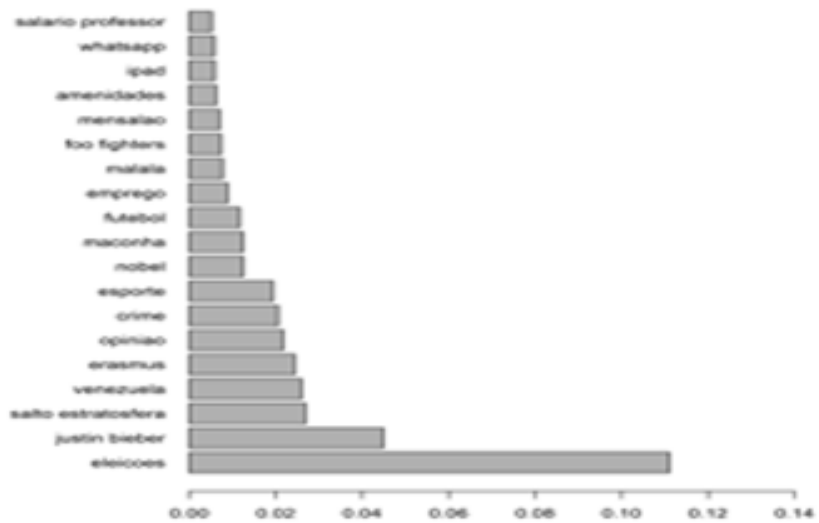

Source: elaborated by the authors 
Figure 1 shows the main issues covered by news outlets in the countries included in this study during the period. The top replicated event on Twitter in the period was elections: $11 \%$ of the topics among the top 25 tweets in each newspaper, likely due to the fact that three of the five countries analyzed in this study were holding election polls. The second most replicated theme, with $4.5 \%$ of the top replicated messages on Twitter, is pop singer Justin Bieber, confirming the information provided by a Twitter employee in 2010 , that tweets about the singer always occupy $3 \%$ of Twitter servers (AXON, 2010).

The prominence of Justin Bieber on Twitter can be appreciated by analyzing the top retweeted message in the period. Across all newspapers covered in this study, the message with the highest number of replications is a tweet posted by Justin Bieber himself with a link to a news piece from The Washington Post about his career (Figure 2). This piece of news was replicated over 10,000 times in the two weeks of the study - an average of 785 replications per day. The tweet helped increase the percentage of messages about Justin Bieber to $4.5 \%$ of the total number of posts replicated (Figure 1). Although news about Justin Bieber was largely replicated, soft news items are an exception at the top replicated news on Twitter.

Figure 2 Tweet from Justin Bieber with a link to The Washington Post replicated over 10,000 times

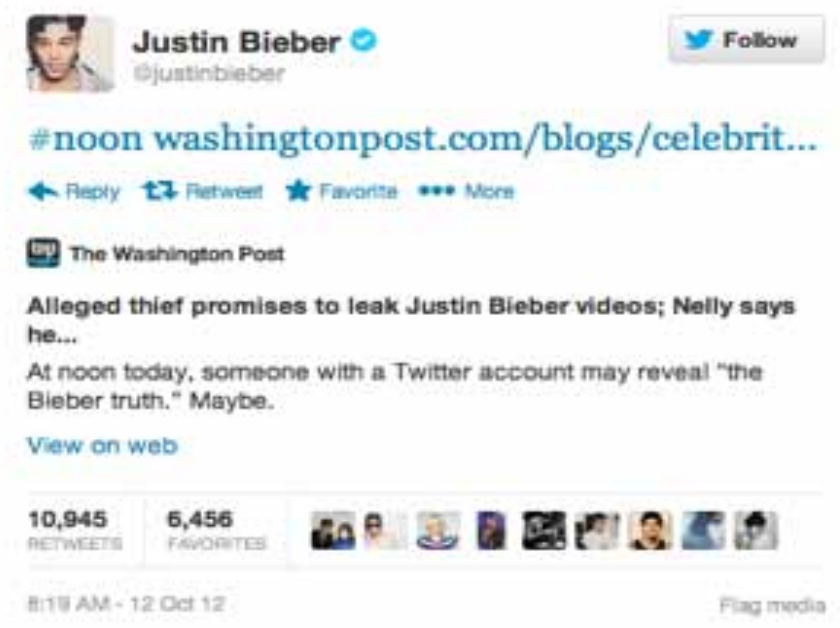

Source: twitter.com/justinbieber 
There were regional variations across countries, with a predominance of news about sport, elections, and corruption in Brazil, and a greater coverage of crimes and unemployment in the United States (possibly due to the polls being held during the period). News about the end of the Erasmus scholarship and the instability on Whatsapp servers featured only in Spain, and the announcement of the death of TV presenter Dirk Bach appeared only in Germany. In addition, there was a much higher proportion of opinion pieces in the United Kingdom with no prevailing issue.

Despite the variety of sections and topics reported, there was a considerable number of events covered in all the countries, confirming the international impact of a small set of news items and the global news coverage. Events reported in most of the countries investigated include: Felix Baumgartner's jump to Earth from a helium balloon in the stratosphere; the announcement of the Nobel Laureates; the elections in Venezuela; and the death of historian Eric Hobsbawn. All events happened or were announced in the period between the $1^{\text {st }}$ and $14^{\text {th }}$ of October, 2012. In addition, elections proved to be a topic covered by newspapers in all countries. Figure 3 shows the attention share that each theme received in the countries considered.

Figure 3 Relative audience of international news on Twitter per country

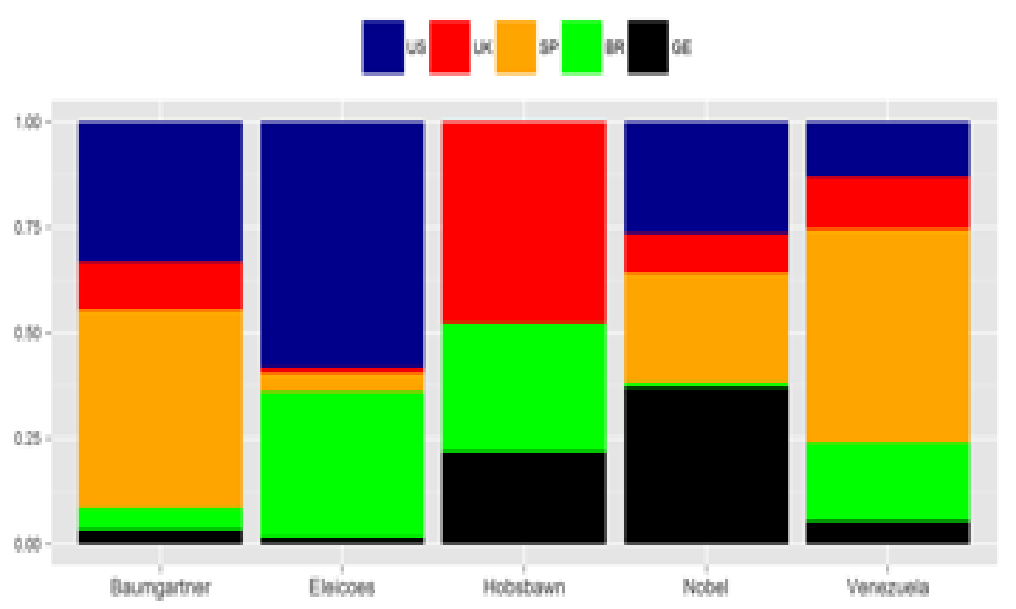

Source: elaborated by the authors. 


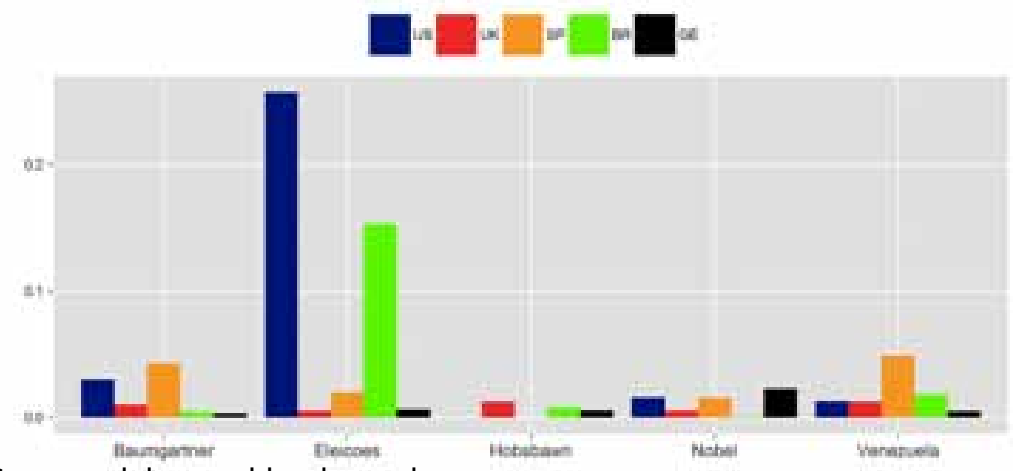

Source: elaborated by the authors.

Figure 3 presents the relative distribution of each topic per country. Figure 4 shows the relative audience of each global item in the five countries studied. As a general trend, news coverage in the United States is seemingly more comprehensive, as global news items are covered extensively in the country. An interesting and perhaps disturbing exception is the death of the Marxist historian Eric Hobsbawn, which can perhaps be explained by the polarized political context in the US and the limited intellectual projection that Marxist intellectuals have in the country.

Interestingly, the countries where news items about Hobsbawn's death circulated more were, in descending order: the United Kingdom, Brazil and Germany. Eric Hobsbawn was an Egyptian-born British historian and the impact of the news in the United Kingdom was to be expected. Hobsbawn's books were translated, published and much debated by Brazilian and German scholars, which also explains the relative difference from the circulation in countries such as Spain and the United States, where the news failed to gain momentum.

News about Venezuelan elections had a disproportionately high incidence in Spain. This can be explained due to socioeconomic and political ties between the countries (Venezuela was a colony of Spain until 1823). Moreover, it can be hypothesized that a significant portion of the audience of Spanish newspapers are Venezuelan and South American readers. Therefore, the larger impact of the topic in Spain was somewhat expected, particularly in comparison to the other countries discussed.

Felix Baumgartner's jump to Earth from a balloon in the stratosphere was one of the most intensively discussed and replicated 
events across the countries. In Spain, and this is another relevant exception, Baumgartner's jump received a proportionally larger attention share compared to the other counties. Elections attracted considerable attention in the United States and Brazil, but were less covered in the other countries. The announcement of the 2012 Nobel Peace Prize to the European Union (EU) is another of the few topics discussed in all countries, but whose coverage and discussion by the Brazilian audience - likely due to the country's geographic position - is significantly lower than in the other countries.

\subsection{Top replicated topics on Facebook}

While the top replicated news items on Twitter consisted mainly of hard news events, there was a prevalence of soft news items among the top "liked" articles on the newspapers' pages on Facebook.

Figure 5 Relative proportion (\%) of the top "liked" news on Facebook in the newspapers analyzed

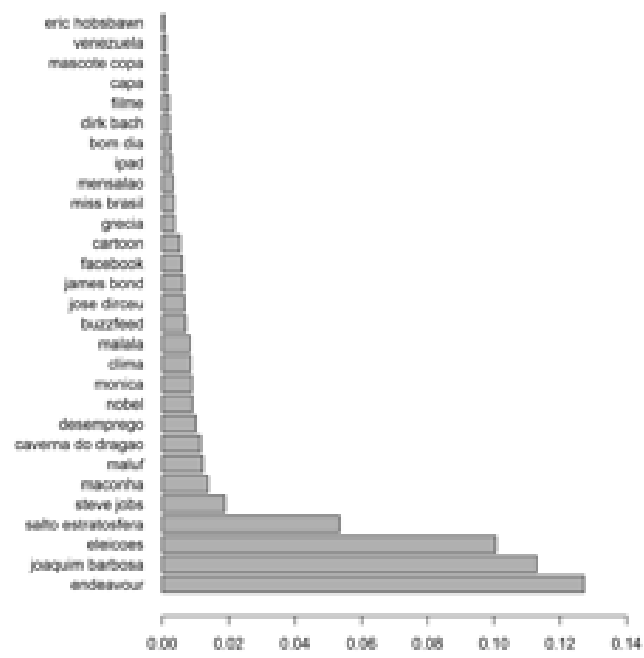

Source: elaborated by the authors

Figure 5 shows the top items covered by newspapers across all the countries. Although the most "liked" event appeared only on North American fanpages, $12.7 \%$ of the total number of "likes" refer to pictures of the retirement and transportation of the Endeavour space shuttle through the streets of Los Angeles to the California Science Center. This event was the top liked news in the period by a considerable margin - a 
news article covering the event published by The New York Times on its Facebook page, for example, received 19,000 likes. Figure 6 shows the picture of Endeavour on the streets of Los Angeles published by The New York Times on October 13.

Figure 6 Message posted by The New York Times on Facebook with over 19,000 likes

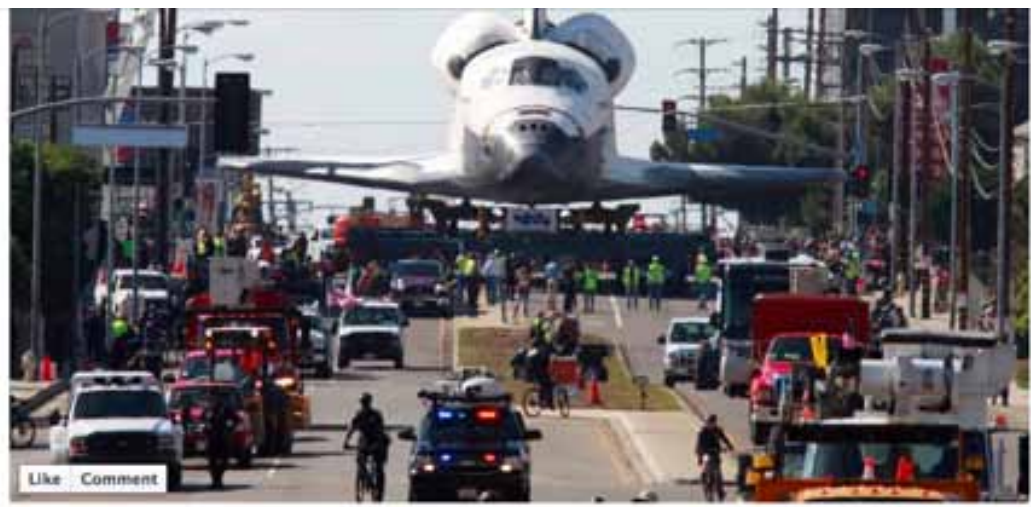

The New York Timei

The Space Shutale Endesvour began ats mo-day crawel through Los Angeles to iss retirement at the Calforna Science Center. (Photo by Nonica

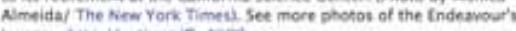
journey: hita:limptimu/Owhorrh

vie - Comment - Shave - October 13. 2013

16) 19,003 people sike this.

Noume: Timeline Fhotos Shared with 6 Ratic Oven Hrooo Virwer Downiase Nepert

Source: facebook.com/nytimes

The second-top replicated news item, with $11.3 \%$ of the total number of "likes", was the election of Joaquim Barbosa as the head of the Supreme Federal Court in Brazil, in October 10, 2012 - another event whose coverage was limited to a single country. The top international topic was the elections in the countries discussed, with $10 \%$ of the replications. Although this topic did not appear in Spanish outlets among the top replicated news on Facebook, it featured on Facebook pages of newspapers from Brazil, Germany, the United States and United Kingdom, with a larger-than-average percentage in the United States.

There were also interesting regional differences. In Brazil, the top replicated topic was the announcement of Joaquim Barbosa as the head of the Supreme Federal Court. In Germany and Spain, it was the stratospheric jump of Felix Baumgartner. In the United Kingdom, it was the announcement of the Nobel Laureates, while in the United States, the presidential election was one of the most replicated topics after the Endeavour space shuttle. 
Although elections in the countries investigated represented regular international news, other political events - such as the elections in Venezuela - received a relatively smaller share of attention on Facebook than on Twitter. Perhaps as a confounding effect of this, it was noted that other topics associated with entertainment or soft news replaced the aforementioned events. Figures 7 and 8 show the top liked events, including the most recent James Bond movie and the transportation of the space shuttle Endeavour (Figure 6). They were the most replicated events that appeared on the Facebook page of national newspapers, but not on Twitter. The first anniversary of Steve Jobs's death on October 5, 2012 , is another topic that received considerable attention.

Figure 7 Relative audience of international news on Facebook per

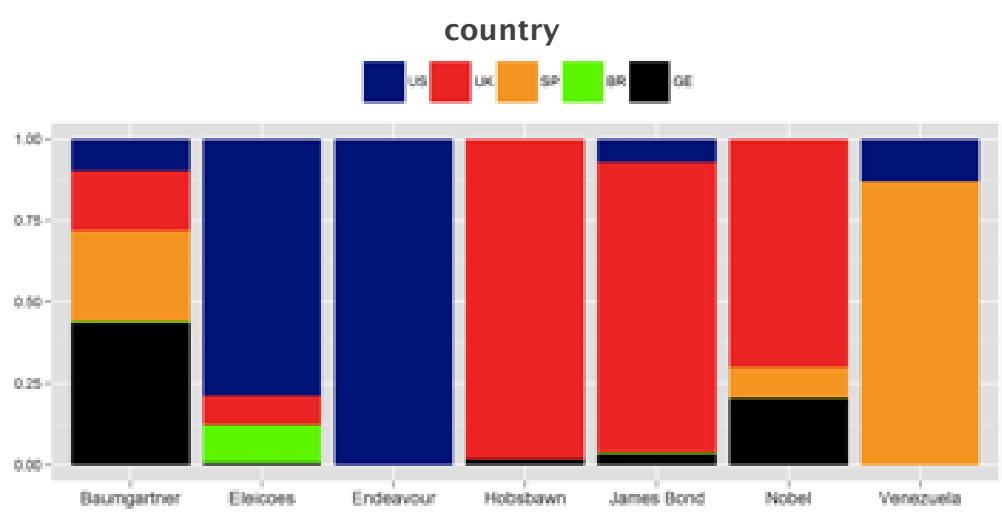

Source: elaborated by the authors.

Figure 8. Volume of top replicated news on Twitter per country

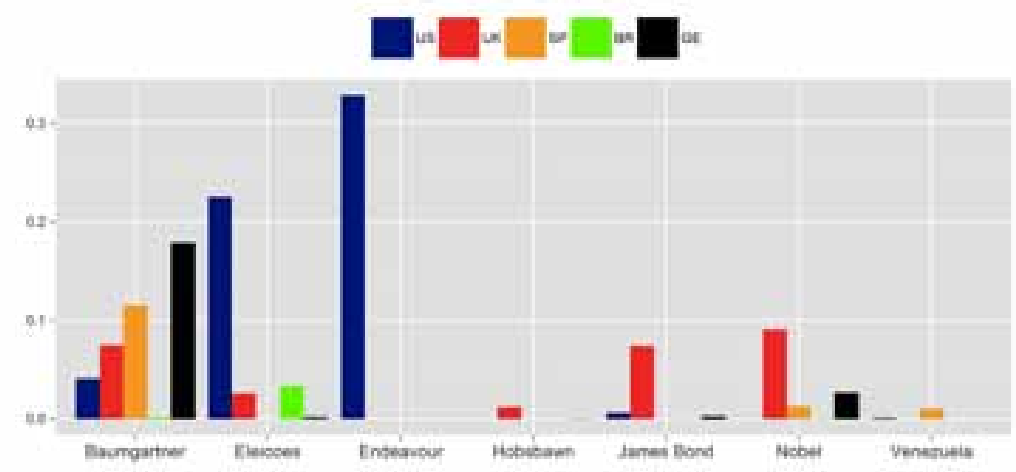

Source: elaborated by the authors. 
Despite the differences, Felix Baumgartner's jump to Earth from a balloon in the stratosphere also appeared on Facebook as a global news item, which circulated as widely on Facebook as on Twitter. Hence, it can be considered that Baumgartner's jump was the top replicated international event across both platforms. In contrast, events that had large audiences on Twitter across the countries investigated in this study, such as the results of the elections in Venezuela and the death of Eric Hobsbawn, were virtually non-existent on newspaper pages on Facebook.

\section{FINAL OBSERVATIONS: TWITTER VS FACEBOOK}

The results presented in this investigation show an empirical confirmation of the user's perception that Facebook is more often used for content related to entertainment and curiosities (soft news), whereas Twitter is mostly used for the coverage of political, economic, and social events (hard news). These are claims largely discussed by users, but until recently there was no literature confirming or disputing them using a quantitative approach to the question. Therefore, the results of this research should contribute to an understanding of the particularities of each digital platform regarding news distribution.

However, the differences reported in this study can be associated with the type of content posted by newspapers on Facebook, rather than with differences between the two platforms. The use of pictures on Facebook, for example, tends to be associated with a higher number of "likes" 3 , which would explain the volume of replications in posts referring to the transportation of the Endeavour space shuttle. Moreover, the format for links to news items on Twitter and Facebook varied considerably. While posts on Twitter frequently pointed to news pieces or blog posts, updates on Facebook pointed to content made available in a variety of formats, including infographics, photo galleries, live feeds, and other types of media.

In a context of spreadable media (JENKINS, FORD; GREEN, 2013), it is important to identify what kind of news is commonly shared across social networking sites. Replication by users, either as "retweets" or "likes", acts as a complement to news circulation through traditional channels and can emphasize or understate particular topics or news items. Finally, it is expected that future investigations will shed additional light on the use of social media by news outlets, perhaps contrasting the agendas of newspapers, social networking sites and public opinion. 


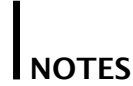

1 News items were classified into one of these 22 sections: arts, cars, classified, crime, economy, education, entertainment, environment, fashion, health, jobs, lifestyle, local news, national news, world, opinion, politics, science, sports, technology, travel and weather.

2 The analyses presented in this paper were performed using the R software (2009), which is a programming language and an integrated platform for statistical calculus, graphic plotting, data mining, and data analysis. Data extraction from Twitter and Facebook APIs was achieved using the RJSONIO and RCurl libraries, combined with programming routines set by the authors.

3 http://danzarrella.com/infographic-how-to-get-more-likes-commentsand-shares-on-facebook.html\#

\section{REFERENCES}

AAM. Top 25 U.S. Newspapers for September 2012. Research and Data. Arlington Heights: Alliance for Audited Media, 2012.

ABC. National Newspapers Report. Berkhamsted: Audit Bureau of Circulations, 2012.

ANJ. Maiores jornais do Brasil. Associação Nacional de Jornais, 2011.

AXON, S. 3\% of Twitter's Servers Dedicated to Justin Bieber. Mashable, 7 set. 2010. Available at: <http://mashable.com/2010/09/07/justin-biebertwitter/>. Accessed on : Apr. 24, 2013.

BRUNO, N. Tweet first, verify later? How real-time information is changing the coverage of worldwide cirsis events. Oxford: Reuters Institute, 2011. 77 p. Available at: <https://reutersinstitute.politics.ox.ac.uk/fileadmin/ documents/Publications/fellows__papers/2010-2011/TWEET_FIRST_VERIFY_ LATER.pdf>. Accessed on: Apr. 24, 2013.

BRUNS, A.; HIGHFIELD, T. Blogs, Twitter, and Breaking News: The Produsage of Citizen Journalism. In: ANN LIND, R. (Eds.). Produsing Theory in a Digital World: The Intersection of Audiences and Production. New York: Peter Lang, 2012. p. 15-32.

CONOVER, M. D. et al. Political Polarization on Twitter. In: ICWSM, 5, 2011. Barcelona. Proceedings... AAAI Press, 2011.

DALMASO, S. Uma fanpage para compartilhar links: a utilização do Facebook pelo jornal Diário de Santa Maria. In: SIMPÓSIO NACIONAL DA ABCIBER, 6, 2012. Proceedings...Novo Hamburgo, RS: ABCiber, 2012.

HARGITTAI, E.; LITT, E. The tweet smell of celebrity success: Explaining 
variation in Twitter adoption among a diverse group of young adults. New Media \& Society, v. 13, n.5, p. 824-842, 2011

HERMIDA, A. Tweets and Truth: Journalism as a discipline of collaborative verification. Journalism Practice, v. 6, n. 5-6, p. 659-668, 2012.

IVW. 2012 Auflagenliste. Berlin: Informationsgemeinschaft zur Feststellung der Verbreitung von Werbeträgern e.V., 2012.

JENKINS, H.; FORD, S.; GREEN, J. Spreadable Media. New York: NYU Press, 2013. $352 \mathrm{p}$.

JÚNIOR, F. Do papel ao Facebook: outras textualidades midiáticas no jornalismo da Folha de S. Paulo. RELEM, v. 6, n. 1, 2013.

KISCHINHEVSKY, M. Radiojornalismo comunitário em mídias sociais e microblogs: circulação de conteúdos publicados no portal Radio Tube. Estudos em Jornalismo e Mídia, v. 9, n. 1, p. 136-149, 2012.

MACHADO, E. Sistemas de circulação no ciberjornalismo. Eco-Pós, v. 11, n. n, p. 21-37, 2008.

MITCHELSTEIN, E.; BOCZKOWSKI, P. J. Between tradition and change: A review of recent research on online news production. Journalism, v. 10, n. 5, p.562586, 2009.

NEWMAN, N. Mainstream media and the distribution of news in the age of social discovery. Oxford: Reuters Institute, 2011.58 p. Available at: <https:// reutersinstitute.politics.ox.ac.uk/fileadmin/documents/Publications/ Working_Papers/Mainstream_media_and_the_distribution_of_news_.pdf>. Accessed on: Apr. 24, 2013.

OJD. Diarios (Daily Newspapers). In: DIFUSIÓN, O. D. J. D. L. (Eds.) Medios Controlados. Madrid, 2012.

PRIMO, A. Transformações no jornalismo em rede: sobre pessoas comuns, jornalistas e organizações; blogs, Twitter, Facebook e Flipboard. Intexto, v. 2, n. 25, p. 130-146, 2011.

R DEVELOPMENT CORE TEAM. R: A language and environment for statistical computing. Vienna: R Foundation for Statistical Computing, 2009.

RECUERO, R. Redes sociais na internet. Porto Alegre: Sulina, 2009. 206 p.

REINEMANN, C. et al. Hard and soft news: A review of concepts, operationalizations and key findings. Journalism, v. 13, n. 2, p. 221-239, 2012.

THORN, W.; PFEIL, M. Newspaper Circulation: marketing the news. New York: Longman, 1987. 333 p.

VIS, F. Twitter as a reporting tool for breaking news. Digital Journalism, v. 1, n. 1, p. 27-47, 2012.

ZAGO, G. Da circulação à recirculação jornalística: filtro e comentário de notícias por interagentes no Twitter. In: ENCONTRO ANNUAL DA COMPÓS, 21, 2012. Proceedings... Juiz de Fora, MG: Compós, 2012. Available at: <http:// www.compos.org.br/pagina.php?menu $=8 \&$ mmenu $=0 \&$ fcodigo $=1896>$. Accessed on: Fev. 5, 2013. 
ZAGO, G.; RECUERO, R. Jornalismo em microblogs: um estudo das apropriações jornalísticas do Twitter. In: SILVA, G.; KÜNSCH, D.; BERGER, C.; ALBUQUERQUE, A. (Eds.). Jornalismo contemporâneo: figurações, impasses e perspectivas. Salvador/Brasília: EDUFBA/Compós, 2011, p. 243-266.

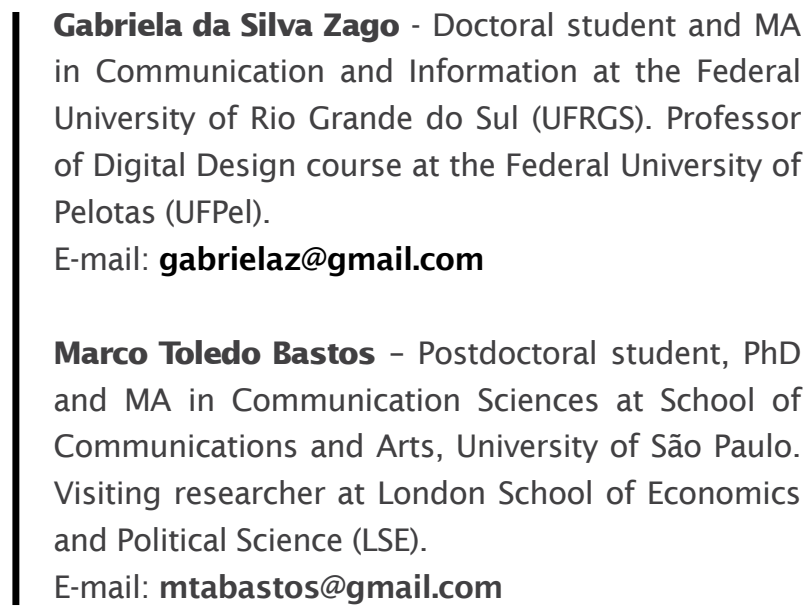

